\title{
PERILAKU BULLYING DALAM PERSEKTIF BIMBINGAN DAN KONSELING ISLAM
}

\author{
Ibnu Mahmudi*
}

\begin{abstract}
Abstrak
Perilaku bullying adalah bentuk-bentuk perilaku yang berupa pemaksaan atau usaha menyakiti secara fisik maupun psikologis terhadap seseorang atau kelompok yang lebih "lemah" oleh seseorang atau sekelompok orang yang mempersepsikan dirinya "kuat". Bullying adalah penggunaan kekuasaan atau kekuatan untuk menyakiti seseorang atau sekelompok, sehingga korban merasa tertekan, trauma dan tidak berdaya.

Hasil penelitian yang dilakukan Giri Rahendra tahun 2012 SMP Negeri 1 Maospati, menunjukkan bahwa 60\% diantara siswa terdapat indikasi merupakan korban dan pelaku bullying, selain itu di setiap kelas terdapat gank pengelompokan teman.

Perbuatan Bullying ini dapat dikategorikan sebagai salah satu bentuk kenakalan remaja atau siswa di sekolah yang harus segera di selesaikan agar tidak mengganggu perkembangan siswa. Langkah yang dapat dilakukan adalah melalui peningkatan layanan bimbingan dan konseling agama (Islam)
\end{abstract}

Kata Kunci: Perilaku Bullying, Kenakalan Remaja, Bimbingan dan Konseling Islami. 
Pendahuluan

Perilaku Bullying merupakan salah satu bentuk perilaku yang menyimpang dari pola perilaku individu/siswa pada umumnya. Perilaku tersebut sering digunakan oleh remaja dalam hal ini adalah siswa untuk menindas temannya yang lebih lemah. Perilaku ini dikenal dengan istilah bullying. Rigby (2003) menjelaskan bullying adalah bentuk-bentuk perilaku yang berupa pemaksaan atau usaha menyakiti secara fisik maupun psikologis terhadap seseorang atau kelompok yang lebih "lemah" oleh seseorang atau sekelompok orang yang mempersepsikan dirinya "kuat". Bullying adalah penggunaan kekuasaan atau kekuatan untuk menyakiti seseorang atau sekelompok, sehingga korban merasa tertekan, trauma dan tidak berdaya.

Fenomena bullying semakin mengemuka setelah terdapat korban-korban yang meninggal dan diekspose oleh media secara luas. Contoh kasus bullying adalah kasus yang terjadi di SMA 70 Bulungan, Jakarta Selatan. Kasus tersebut melibatkan tiga orang siswi sebagai pelaku dan satu orang siswi sebagai korban. Kejadiannya bermula saat salah seorang dari pelaku yang juga senior dari korban memanggil korban dan menegur korban karena tidak memakai kaos dalam dan baju yang dikenakannya transparan. Teguran yang disampaikan oleh siswi senior ternyata membuat korban merasa teraniaya dan tidak berani melawan hingga korban menangis (Solopos, 2011). Peristiwa terbaru adalah yang terjadi di SMA Seruni Don Bosco, Pondok Indah, Jakarta Selatan. Kasus ini berawal dari seorang siswa baru yang mengikuti masa orientasi siswa (MOS) di SMA Seruni Don Bosco yang diduga menjadi korban bullying oleh kakak kelasnya, mengaku dipukuli dan disundut rokok di sekolahnya oleh kakak kelasnya. Kini kasus ini masih ditangani oleh pihak kepolisian (Tempo.co.id, 2012).

Fenomena serupa juga terjadi di SMP Negeri 1 Maospati Magetan sebagaimana laporan hasil penelitian bersama Giri Rahendra dengan penulis. Berdasarkan pengamatan peneliti menunjukkan bahwa $60 \%$ diantara siswa 
terdapat indikasi merupakan korban dan pelaku bullying, selain itu di setiap kelas terdapat gank pengelompokan teman. Hampir semua siswa korban bullying menunjukkan tingkat kepercayaan diri dan minat belajar yang rendah dan cenderung menjadi individu yang pendiam dan tertutup sehingga siswa tidak bisa mengoptimalkan potensi diri yang dimilikinya.

Pelaku bullying pada umumnya memiliki ciri khas yaitu agresivitas yang tinggi dan kurang empati. Sementara itu, pada korban, yang perlu ditingkatkan adalah sikap ketegasan dan kepercayaan dirinya. Dengan demikian, bentuk-bentuk bantuan yang perlu diberikan kepada korban hendaknya fokus kepada upaya meningkatkan sikap ketegasan dan kepercayaan dirinya.

\section{Pembahasan}

Berbagai peristiwa yang mencerminkan adanya perilaku bullying tersebut tentu saja ada penyebabnya, pada artikel ini penulis berasumsi bahwa salah satu penyebabnya adalah remaja/siswa di sekolah kurang bisa memahami dan mengamalkan ajaran agama.

A. Bimbingan dan konseling agama.

Pengertian bimbingan dan konseling agama menurut beberapa ahli diantaranya: (1) Arifin (dalam Samsul Munir Amin, 2008, hal 19), bimbingan dan konseling agama adalah segala kegiatan yang dilakukan oleh seseorang dalam rangka memberikan bantuan kepada orang lain yang mengalami kesulitan-kesulitan rohaniah dalam lingkungan hidupnya agar orang tersebut mampu mengatasinya sendiri karena timbul kesadaran dan penyerahan diri terhadap Tuhan Yang Maha Esa, sehingga timbul pada diri pribadinya suatu cahaya harapan kebahagiaan hidup masa sekarang dan masa depannya. (2) Wayne, E. Qates (dalam Samsul Munir Amin, 2008, hal. 21), mengatakan bahwa "There is no easy road to becaming a good religious counselor, any more than there is an easy road to becoming any kind of effective counselor". (Tidak ada jalan yang 
mudah dilalui untuk menjadi konselor agama yang baik, sedangkan mendapatkan jalan untuk menjadi konselor yang efektif dalam bidang apapun adalah lebih mudah. (3) Sejalan dengan pendapat di atas Carl Gustave Jung (dalam Samsul Munir Amin, 2008, hal. 21), mengemukakan bahwa pasienpasien yang diobati sebagian besar menderita penyakit dikarenakan tidak memperoleh cahaya dari nilai-nilai agama dalam diri mereka. Penyembuhannya tidak dapat diperoleh, kecuali apabila yang bersangkutan mendapatkan kembali cahaya dari nilai-nilai keagamaannya.

Berdasakan pendapat di atas maka pelaksanaan bimbingan dan konseling agama di sekolah-sekolah dapat dilakukan oleh para guru agama dengan bantuan fasilitas administratif dan kepala sekolah, sebab fungsi dan tugas guru agama di sekolah bukanlah terbat as pada dinding kelas saja melainkan kepada kegiatan bimbingan di luar kelas, bahkan di masyarakat dan keluarga.

B. Bimbingan dan konseling Islami.

1. Pengertian bimbingan dan konseling didefinisikan oleh beberapa ahli diantaranya: (1) Anwar Sutoyo, (2007, hal. 24-25) Hakekat bimbingan dan konseling Islami (Qur'ani) adalah upaya membantu individu belajar mengembangkan fitrah dan atau kembali kepada fitrah, dengan cara memberdayakan (empowering) iman, akal, dan keamanan yang dikaruniakan Allah swt, kepadanya untuk mempelajari tuntunan Allah dan rasul-Nya, agar fitrah yang ada pada individu itu berkembang dengan benar dan kokoh sesuai dengan tuntunan Allah swt. (2) Samsul Munir Amin, (2008, hal.23-24) Bimbingan dan konseling islami adalah proses pemberian bantuan terarah kontinu dan sistematis kepada setiap individu agar ia dapat mengembangkan potensi atau fitrah beragama yang dimilikinya secara optimal dcengan cara menginternalisasikan nilai-nilai yang terkandung di dalam Alqur'an dan hadis 
Rasulullah saw ke dalam dirinya, sehingga ia dapat hidup selaras sesuai dengan tuntunan Alqur'an dan hadis.

\section{Tujuan Bimbingan dan Konseling Islami}

Aunur Rahim Faqih (2004, hal 63-64), tujuan bimbingan dan konseling keagamaan Islami dapat dirumuskan sebagai berikut:

a. Membantu individu/kelompok individu mencegah timbulnya masalahmasalah dalam keagamaan, antara lain dengan cara: 1) memahami individu menyadari fitrah manusia, 2) membantu individu mengembangkan fitrahnya. (mengaktualisasikannya), 3) membantu individu memahami dan menghayati ketentuan dan petunjuk Allah dalam kehidupan keagamaan, 4) membantu individu menjalankan ketenentuan dan petunjuk Allah mengenai kehidupanaan.

b. Membantu individu memecahkan masalah yang berkaitan dengan kehidupan keagamaannya, antara lain dengan cara: 1) membantu individu memahami problem yang dihadapinya, 2) membantu individu memahami kondisi dan situasi dirinya dan lingkungannya, 3) membantu individu memahami dan menghayati berbagai cara untuk mengatasi problem kehidupan keagamaannya sesuai dengan syariat Islam, 4) membantu individu menetapkan pilihan upaya pemecahan problem keagamaan yang dihadapinya.

C. Bimbingan dan Konseling Bagi Kenalakan Remaja.

Bimbingan dan Konseling agama di kalangan remaja pada khususnya di luar sekolah dan dalam masyarakat yang sedang mengalami transisi menuju ke kehidupan modern yang berbeda dengan tuntutan dan keinginan orang tua dianggap sebagai permasalahan serius, antara lain adalah masalah kenalakan remaja, mengingat remaja adalah suatu kelompok usia yang diharapkan menjadi penerus cita-cita bangsa, remaja harus memiliki kondisi mental psikologis yang lebih besar kemampuannya serta kesanggupannya dari generasi 
sebelumnya. Harapan demikian, hendaknya dipersiapkan dalam jiwa para remaja melalui bimbingan dan konseling yang intensif dan ekstensif, agar remaja kenakalan remaja yang potenial di masa yang akan datang.

Dalam tingkat perkembangan hidup kejiwaan remaja terutama pada periode pubertas atau adolesens, remaja sering dilanda keguncangankeguncangan yang tidak jarang muncul dalam bentuk perbuatan yang disebut "juvenile delinquency" atau kenakalan remaja dengan gejala yang mengkhawatirkan terhadap kelangsungan hidup negara dan bangsa. Karenanya masalah kenakalan remaja dipandangan sebagai problem sosial yang perlu mendapat perhatian oleh setiap orang tua, khsusnya bagi pekerja bidang bimbingan dan konseling.

Problem remaja terdapat hampir dalam semua masyarakat diberbagai kota dimanapun didunia. Karena hal ini merupakan salah satu gejala dari perkembangan masyarakat itu sendiri sebagai suatu totalitas kehidupan.

Sebenarnya problem ini muncul bukan hanya sebab dari satu atau dua fakor saja, melainkan muncul dari banyak faktor yang saling mempengaruhi antara satu dengan yang lainnya. Itulah sebabnya pendekatan terhadap problem tersebut harus di dasarkan atas problem solving-attitudes (sikap untuk memecahkan masalah yang dapat memantulkan suatu pengertian dasar yang berorientasi kepada kenyataan-kenyataan hidup dalam masyarakat itu sendiri)

Problem remaja semacam ini dalam masyarakat Indonesia dapat di dekati dengan berbagai pendekatan, tetapi pembimbing dan konselor harus melihat atau memilih tingkat dari intensitas problem dalam segi-segi kehidupan tersebut.

\section{Juvenile Delinquency Sebagai Suatu Masalah}

Problematika yang muncul(kenakalan) dengan nondelinquency (bukan kenakalan). Menurut H.M. Arifin (dalam Syamsul Munir Amin, 2008, hal. 368), bahwa batas bawah dan batas atas dari usia anak adalah menjadi 
penentu bagi perbuatan delinquency dan nondeliquency tersebut. Pada umumnya para psikolog, ahli pedagogik, sosiolog, dan kriminolog memberikan batas bahwa kenakalan remaja (juvenile deliquency) adalah tingkah laku atau perbuatan yang berlawanan dengan hukum yang berlaku, yang dilakukan anak-anak antara umur 10 tahun sampai umur 18 tahun tahun. Perbuatan yang dilakukan oleh anak-anak di bawah 10 tahun dan di atas 18 tahun, dengan sendirinya tidak dikategorikan dalam apa yang disebut kenakalan (deliqunecy) tersebut.

Kenakalan remaja merupakan suatu problem sosial. Mengapa demikian? Kenakalan remaja dipandang sebagai suatu problem sosial karena beberapa sebab, yaitu sebagai berikut:

a. Kenakalan remaja dapat menganggu ketertiban sosial dan hukum.

b. Kenakalan remaja dapat merugikan perkembangan generasi muda itu sendiri.

c. Kenakalan remaja dapat mengganggu jalannya perkembangan sosial pedagogis, sosial ekonomi, dan kebudayaan bangsa.

Kenakalan remaja bukanlah masalah kriminologisaja tentunya tetap mempertimbangkan kemasalahatn bersama dan masa depan generasi muda khususnya remja, agar perkembangan pribadi para remaja tetap terpelihara dan tidak merugikan remaja itu sendiri sebagai angggota masyarakat dan warga negara yang baik.

Tindakan represif, misalnya anak nakal dikenakan hukuman yang bagaimana yang dikenakan kepada penjahat atau pelaku kriminal. Mengapa diperlakukan demikian? Karena remaja masih berada dalam tahap perkembangan jiwa yang memiliki banyak kemungkinan untuk mengubah dirinya menjadi lebih baik di masa dewasanya.

Pembimbing dan konselor hendaknya perlu memahami latar belakang dari perbuatan kenakalan remaja itu sendiri. Dengan dasar 
pengetahuan latar belakang inilah kemudian pembimbing dan konselor dapat melakukan perbaikan-perbaikan dan arahan-arahan yang konstruktif dan positif. Jika pembimbing dan konselor mengetahui secara mendalam latar belakang yang menyebabkan kenakalan remaja tersebut, maka cara-cara penyelesaiannya dapat dilakukan dengan cara dapat dilakukan dengan cara yang tidak merugikan berbagai pihak.

\section{Faktor-faktor Yang Menyebabkan Kenakalan Remaja}

Dalam berbagai kajian psikologi sosial yang menyangkut masalah remaja, biasanya disebutkan bahwa yang menyebabkan terjadinya kenakalan remaja dikarenakan faktor-faktor berikut

\section{a. Faktor Makro: Faktor Sekitar atau Lingkungan (Environment)}

Faktor sekitar atau lingkungan merupakan faktor-faktor makro penyebab terjadinya kenakalan remaja. Di antara faktor sekitar atau lingkungan yang dapat menyebabkan timbulnya kenakalan remaja adalah sebagai berikut:

1) Keadaan Ekonomi Masyarakat

Menurut Nye, Short, dan Olson (dalam Syamsul Munir Amin, 2008, hal. 370) yang mengadakan penelitian di Amerika Serikat, kenakalan anakanak atau revmaja ada hubungannya dengan masalah taraf sosial-ekonomi keluarga. Status sosial-ekonomi yang rendah dari suatu keluarga lebih banyak mendorong anak-anak dan remaja menjadi nakal (delinquency). Dalam penelitian tersebut dikemukakan bukti bahwa 50\% anak dari Lembaga Pendidikan Anak-Anak Nakal (Correction Center) di Amerika Serikat, yang terdiri dari 146 anak laki-laki berasal dari keluarga yang sosial-ekonominya rendah, dan hanya $4,1 \%$ dari keluarga yang sosioekonominya tinggi.

Status sosio-ekonomi tersebut dapat di evaluasi menurut kombinasi dari pendapatan keluarga ayah, pendidikan, dan lingkungan tetangga dimana keluarga itu hidup. Dengan demikian, penyelesaian terhadap 
problem kenakalan remaja ini harus dengan meningkatkan taraf sosioekonomi keluarga yang relatif masih rendah, yang dalam pelaksanaannya lebih lanjut akan menyangkut banyak persoalan yang kom, yang dalam pelaksanaannya lebih lanjut akan menyangkut banyak persoalan yang kompleks. Misalnya lapangan pekerjaan baru, upah buruh yang meningkat, inflasi dan kestabilan harga, dan hal-hal yang berkenaan dengan peningkatan ekonomi.

2) Masa atau Daerah Peralihan (Transitional Area)

Masa atau daerah transisi dalam segala bidang, misalnya menyangkut masalah politik, ekonomi, sosial dan budaya dapat menjadi sebab pemicu terjadinya kenakalan remaja. Hal ini disebabkan masa atau daerah transisi dapat membawa kepada keguncangan-keguncangan psikologis dari suatu masyarakat, terutama di kalangan anak-anak dan remaja di mana perkembangan kejiwaan masih dalam masa transisi pula, yaitu masa pubertas dengan gejala-gejalanya Strum und Drang. Oleh karena itu, faktor ini lebih mudah mempengaruhi anak-anak atau remaja yang kemudian menyebabkan terjadinya kenakalan remaja.

Pada masa permulaan kemerdekaan Negara Indonesia, muncullah masa taransisi yang mendorong keluarga yang rendah lebih banyak, yang kemudian mendorong pula masa transisi psikologis di kalangan remaja dalam proses menemukan "national identity". Dengan demikian, kenakalan yang muncul dapat dikatakan sekadar akibat dari tingkat hidup politis terjajah kepada tingkat hidup yang merdeka, maka situasi seperti ini dapat mengakibatkan munculnya kenakalan remaja.

Masa transisi juga terjadi dari masa agraris menuju masa industri. Hal ini sebagaimana penelitian yang dilakukan oleh Shaw, Zorbaugh, Mc Kay, dan Cottell pada tahun 1929 di dunia Barat. Menurut penelitian ini, faktor peralihan tingkat hidup agraris ke tingkat industri menyebabkan munculnya 
kenakalan remaja paling tinggi daripada yang terdapat di daerah-daerah lainnya. Hal ini dikarenakan daerah transisi tersebut mengalami kemiskinan yang hebat, penduduk berkurang, kebudayaan berantakan, demikian pula terjadi keguncangan-keguncangan dalam masyarakatnya. Akibatnya, kode-kode tingkah laku kelompok hidup masyarakat terjadi keguncangan dan dorongan sosial terhadap individu untuk menyesuaikan diri dengan standar menjadi lemah. Keadaan semacam ini pernah pula terjadi di Chicago pada tahun 1925 dan sekitar tahun 1940. Demikian pula di Indonesia, masa transisi pernah terjadi pada masa-masa lampau.

Sebenarnya masa transisi tersebut dapat dikontrol dan diatur sedemikian rupa agar tidak menimbulkan keguncangan-ekguncangan kultural dan psikologis di kalangan masyarakat.

3) Keretakan Hidup Keluarga (Family Breakdown)

Akibat keretakan hidup keluarga (family breakdown), anak-anak dan remaja terlibat dalam masalah kenakalan remaja. Bahkan karena hubungan yang dekat antara kenakalan remaja dengan family breakdown, banyak para peneliti seperti Sheldon dan Glueck (1957) menyatakan bahwa delinquency menjadi gejala gejala sangat penting dari family breakdown, baik karena keluarga itu mengalami disintegrasi, atau karena tekanantekanan emosional, kematian atau perceraian, maka anak-anak kzxehilangan rasa kasih sayang dari orangtuanya, kehilangan rasa aman serta kebutuhan-kebutuhan fisik dan kesempatan-kesempatan sosial lainnya.

Disamping itu,diakui juga ada hal sebaliknya yaitu kenakalan remaja timbul karena orangtua terlalu overprotective (terlalu memanjakan) terhadap anaknya, walaupun sebenarnya hal ini jarang terjadi.

b. Faktor Mikro: Kepribadian (Personality) Remaja itu Sendiri 
Faktor kepribadian (personality), yaitu faktor yang menyebabkan kenakalan remaja itu muncul dari dalam diri remaja itu sendiri. Adapun faktor mikro yang berhubungan dengan hal ini ada tiga masalah, yaitu sebagai berikut:

1) Faktor atau Cara Mengasuh Anak (Child Rearing Practices)

Cara mengasuh anak yang keliru dapat menimbulkan munculnya kenakalan remaja. Hal ini ada hubungannya dengan masalah pendidikan keluarga. Pendidikan keluarga memiliki pengaruh yang sangat besar bagi perkembangan anak-anak dan remaja dalam hubungannya dengan tingkah laku serta perkembangannya. Di sinilah letak perkembangan pribadi anak yang berkisar pada hubungan orang tua dan anak-anaknya.

Sheldon (1950) menemukan kenyataan yang berupa ciri-ciri kehidupan keluarga yang ada hubungannya dengan kenakalan remaja adalah sebagai berikut:

a) Terlalu mengekang (keras) atau disiplin yang kendur dari ayah terhadap anak laki-laki.

b) Tidak adaya pengawasan anak laki-laki oleh ibunya

c) Tidak adanya rasa kasih sayang ayah terhadap anak laki-laki

d) Tidak adanya rasa kasih sayang ibu terhadap anak laki-laki

e) Tidak adanya rasa saling terikat antara anggota keluarga

Dengan demikian, timbullah jurang pemisah yang mencolok antara orang tua dengan remaja dan jurang pemisah ini akan semakin melebar jika tidak ada usaha-usaha untuk mempersempit jurang pemisah tersebut. Akibatnya, muncul suatu anggapan bahwa orang tua harus mengikuti kehendak anak-anaknya dengan tanpa seleksi, dimana hal ini adalah suatu bentuk kesalahan orang tua dalam berkomunikasi dengan anak. 
Dalam hal ini perlu diadakan re-education bagi orang tua yang telah memiliki pendidikan tinggi, perlu diadakan usaha penyadaran kembali kepada fungsinya dalam melaksanakan tugas-tugas bimbingan dan konseling kepada anak-anak dan remaja.

a) Pengaruh Teman Sebaya (Peer-Group Influence)

Pengaruh teman sebaya dalam pergaulan sangat dominan dalam menciptakan terjadinya kenakalan remaja. Para petugas bimbingan dan konseling harus memperhatikan pengaruh teman sebaya ini, karena terkadang pengaruh dari teman sebaya justru lebih besar pengaruhnya kepada remaja daripada pengaruh orang tua maupun pengaruh guru sekolah.

Beberapa penelitian membuktikan bahwa besar sekali pengaruh teman sebaya dalam memunculkan terjadinya kenakalan remaja di beberapa tempat. Para remaja hendaknya dihindarkan diri dari pergaulan dengan teman yang destruktif yang memunculkan kenakalan. Potensi dan kreativitas remaja hendaknya disalurkan melalui kegiatan yang bisa membangun dinamisasi aktivitas remaja yang sifatnya positif. Kegiatankegiatan positif itu antara lain: kegiatan olah raga, kegiatan seni, kegiatan musik, kegiatan keagamaan, (remaja masjid, dan lain sebagainya)

b) Pengaruh Pelaksanaan Hukum (Law Enforcement Influence)

Apabila pelaksanaan penegakan hukum berjalan tidak adil dan subyektif, dalam arti kurang dapat dipertanggung jawabkan secara objektif, maka faktor ini akan menjadi pendorong bagi anak-anak dan remaja di kalangan keluarga elite dalam membentuk kelompokkelompok anak nakal. Problematika ini hendaknya bisa dihadapi dengan sikap adil dan obyektif yang lebih mementingkan kepentingan orang banyak daripada kepentingan golongan tertentu. 


\section{c. Faktor Makro Yang Menyangkut Personality}

1) Dorongan nafsu yang berlebihan (Impulsiveness)

Dalam kenyataan di kalangan remaja nakal, sifat watak kurang pertimbangan dalam tindakan bahkan bertindak lebih dahulu sebelum berpikir adalah merupakan salah satu ciri-ciri mereka. Bahkan dalam hubungan ini, Healy dan Browner menemukan dalam studinya bahwa 46\% dari anak nakal yang mereka jadikan sampling adalah hyperactive (aktif berlebihan) meskipun istilah "hyperactive" ini tidak dapat dipersamakan dengan "impulsiveness" tersebut.

2) Personality traits dari remaja nakal, antara lain tidak mampu mengadakan penafsiran atau penilaian secara tepat, baik terhadap tingkah lakunya sendiri maupun terhadap orang lain, sehingga mereka tidak dapat melihat dirinya sendiri sebagaimana orang lain melihat dirinya sendiri Itulah sebabnya, mereka tidak mampu memandang dirinya sendiri sebagai obyek sosial yang mengakibatkan mereka tidak mampu menilai tingkah lakunya menurut konsekuensi hidup bermasyarakat. Mereka dengan demikian dapat dikategorikan sebagai "buta moral" (morally blind) atau "social imbicile" yang selalu hidup menurut dirinya sendiri.

3) Negative self concept, yaitu pandangan negatif terhadap dirinya sendiri, juga dipandang sebagai sebab yang lain dari kenakalan remaja. Menurut para ahli seperti Reckless, Dinitts, Murray, 1956 dan Reed dan Cuadra 1957 (dalam Samsul Munir Amin, 2008, hal. 376) kriteria lain yang digunakan untuk membedakan delinquents dan nondelinquents adalah negative self concept ini. Delinquents berpikir kurang baik tentang dirinya dibanding dengan nondelinquents dan kadang sedikit banyak penilaian terhadap dirinya sendiri yang negatif tidak cocok dengan penilaian teman sebayanya terhadap mereka. Jadi, mereka hidup serba dalam alam situasi fantastis, dan sebagainya. 
Oleh karena itu, faktor personality yang terdapat dalam problem individu yang nakal sudah tentu memerlukan pendekatan psikologis. Dengan demikian, konselor yakin bahwa dalam problem tersebut ada interrelasi antara satu faktor dengan faktor lainnya, sehingga kenyataan itu semua akan mendorong konselor untuk menyelesaikan problem kenakalan remaja melalui berbagai segi, melalui interdiciplinary approaches (pendekatan antar ilmuwan)

Sebenarnya masih ada faktor lainnya yang bisa menimbulkan delinquency ini misalnya, kegagalan sekolah (droup out), kecerdasan rendah, kemakmuran ekonomi, pengaruh TV, film porno, film cow boy, buku komik, atau bahkan adolescent development (pubertas), dan sebagainya.

D. Pencegahan Terhadap Kenakalan Remaja

Kenakalan remaja semakin hari semakin ramai dalam pemberitaan, dengan modus dan cara yang beragam. Lalu bagaimana pencegahan dan penanganan kenakalan remaja? Untuk usaha pencegahan kenakalan remaja tersebut, perlu adanya langkah-langkah positif yang dapat diambil untuk pencegahan merambahnya tindak kenakalan remaja di antaranya melalui tindakan-tindakan berikut:

\section{Pendidikan Formal Sekolah}

Pendidikan Formal di sekolah, karena gejala kenakalan sudah dapat diidentifikasi dalam kelas oleh guru, sehingga anak-anak bisa dikenakan pengawasan formal dari sekolahnya. Kvaraceus dan Ulrich 1959 (dalam Samsul Munir Amin 2008: hal 377-378) menggambarkan beberapa program pencegahan timbulnya kenakalan remaja dalam akibat kegagalan perkembangan pribadi anak, maka ada dua macam program untuk pencegahan, yaitu sebagai berikut:

a. Program yang dititikberatkan pada reading instruction. (pengajaran membaca) untuk anak-anak sekolah dasar. 
b. Program work study, yaitu program yang cocok dilakukan pada anak-anak sekolah menengah pertama. Program ini dilancarkan untuk mendorong anakanak yang merasa bahwa sekolah bukan tempat yang memuaskan bagi perkembangan dirinya. Apabila perasaan ini dibiarkan maka akan berkembang menjadi bentuk sikap agresif, yakni permusuhan antara mereka dan guru, atau antar mereka sendiri, dan penolakan terhadap belajar. Program studi kekaryaan ini dapat mengalihkan dorongan nafsu nakal kepada aktivitas berkarya.

2. Community planning, yaitu perencanaan masyarakat dalam hubungan dengan penampungan kegiatan anak atau remaja dalam bentuk organisasi kegiatan sekolah, rekreasi dengan membuat lapangan permainan yang dilengkapi dengan alat permainan yang baik, perkumpulan olah raga, kesenian, organisasi pelajar yang nonafiliasi politis, dan sebagainya.

3. Didirikan perkumpulan-perkumpulan remaja, biro konsultasi dan proyek kegiatan bersama dengan tujuan untuk menyadarkan atau mendidik masyarakat setempat bahwa mereka harus mampu menyelesaikan problem kenakalan anak-anak mereka sendiri dan dapat mengambil tindakan secara kolektif. Sudah tentu mereka perlu mendapat bantuan tenaga ahli seperti social worker, psikolog, skilled educations, psychiatrist atau guidance counselor, dan sebagainya.

4. Pengadilan anak-anak adalah juga dapat digunakan sebagai alat preventif kenakalan remaja. Oleh karena itu, dengan didirikannya pengadilan anak-anak nakal maka berarti mendapatkan alat baru lagi bagi perbaikan masyarakat di kalangan remaja, misalnya dengan pengawasan, meskipun harus diingat sebagai prinsip bahwa pengadilan anak-anak harus memberikan tekanan lebih berat pada segi pedagogis atau rehabilitasi daripada menghukum semata. Hal tersebut dikarenakan perkembangan pribadi anak itu sendiri harus 
mendapatkan prioritas istimewa dengan menyediakan kesempatan yang baik kepadanya.

Dalam menghadapi problem ini konselor harus tidak berat sebelah yaitu menyalahkan anak atau remaja saja, karena mereka sekadar produk dari ketimpangan hidup keluarga atau masyarakat. Oleh karena itu, harus diperhatikan kehidupan keluarga yaitu mendidik kembali orangtua dengan cara-cara yang mungkin juga memperbaiki kehidupan masyarakat secara keseluruhan.

Suatu kenyataan psikologis menunjukkan bahwa seorang anak tidak akan menjadi nakal kecuali jika ia belajar tingkah laku yang nakal, dan bila ia mendapatkan reward atau motivasi ke arah itu. Sumber pokok yang menyebabkan tingkah laku nakal terletak pada orang tua dan teman sebayanya yang nakal pula, yang selalu memberikan dorongan dan rangsangan terhadap perbuatan nakal tersebut.

Dalam hubungan dengan kenakalan remaja, pendidik agama sebagai konselor di samping perlu memahami berbagai faktor penyebabnya, perlu juga memahami berbagai faktor penyebabnya, perlu juga mengambil langkahlangkah preventif dan kuratif.

E. Langkah-langkah Preventif dan Kuratif Menangani Perilaku Bullying sebagai Kenakalan Remaja

Langkah-langkah preventif dan kuratif meliputi prinsip-prinsip sebagai berikut.

a. Di lingkungan sekolah hendaknya selalu bekerja sama dengan guru atau konselor di bidang lain, serta mengadakan diskusi tentang problem remaja tersebut dalam rangka usaha pencegahannya di lingkungan sekolah dan lingkungan masyarakat sekitar.

b. Berusaha membina kerja sama dengan biro konsultasi remaja yang ada, dan pejabat-pejabat peradilan anak-anak atau kepolisian bidang pengawasan anak dan remaja, antara lain guna mendapatkan informasi tentang berbagai kasus 
kenakalan remaja yang pernah ditangani untuk menambah pengertian tentang problem tersebut dalam rangka berpartisipasi pencegahannya lebih lanjut di lingkungan sekolahnya.

Apabila terjadi kasus kenakalan di dalam lingkungan tanggung jawabnya, maka berusaha mengadakan pendekatan kepada remaja yang bersangkutan untuk selanjutnya mengadakan dialog dan wawancara dengan pendekatan psikologis.

c. Hendaknya mempolakan rencana program pencegahan di lingkungan sekolah dengan kegiatan-kegiatan diskusi serta pertemuan den diskusi serta pertemuan dengan siswa di samping kegiatan penyaluran emosi kepada seni budaya serta olah raga dengan bantuan sepenuhnya dari guru-guru lainnya serta kepala sekolah, dan sebagainya.

d. Berusaha membina hubungan kerja sama dengan pihak orang tua atau wali murid yang sebaik-baiknya, serta senantiasa menyampaikan penjelasan tentang pentingnya mereka ikut serta membantu mencegahnya di lingkungan kehidupan keluarga karena peranan orang tua dalam hal sangat besar sekali.

e. Apabila diantara anak bimbingnya dikenakan tahanan karena terlibat pelanggaran hukum, segera mengambil inisiatif bersama sama dengan siswa lainnya untuk mengunjunginya dan memberikan nasehat yang memberikan harapan baik bagi masa depannya.

f. Dalam rangka usaha pencegahannya, konselor agama hendaknya berusaha mengisi konseling di pusat-pusat kegiatan remaja misalnya kalangan komunitas remaja atau youth center, club-club remaja, organisasi remaja lainnya serta memanfaatkan tempat ibadah bagi pembinaan hidup agama remaja dan sebagainya

g. Berusaha menghindarkan remaja dari segala pengaruh media massa yang mengandung unsur-unsur yang merusak moral seperti pornografi, film porno 
dan perkelaihan serta mengawasi kemungkinan terlibat penyalahgunaan obat narkotika atau ganja dan sebagainya.

Sebenarnya masih banyak lagi usaha-usaha pencegahan sesuai dengan kondisi dan situasi yang ada. Akan tetapi, yang perlu diingat dalam tugas konseling agama, konselor agama senantiasa menanamkan pengertian kepada remaja bahwa kaum remaja pun dapat beriman yang teguh dan beragama yang taat, sebagaiman firman Allah SWT dalam Surat Al-Kahfi (18) ayat 13, yang artinya: "Sesungguhnya mereka adalah pemuda-pemuda yang beriman kepada Tuhan mereka, dan Kami tambah pula untuk mereka petunjuk.”

Faktor-Faktor penyebab kenakalan remaja tersebut, bisa dilihat secara lebih jelas dalam bagan sebagai berikut:

\begin{tabular}{|c|c|c|}
\hline Sebab & Faktor Sekitar & Faktor Kepribadian \\
\hline $\begin{array}{l}\text { 1.Faktor } \\
\text { Makro }\end{array}$ & $\begin{array}{l}\text { 1. Keadaan ekonomi } \\
\text { masyarakat } \\
\text { 2.Masa/daerah peralihan } \\
\text { 3.Keretakan hidup keluarga }\end{array}$ & $\begin{array}{l}\text { 1.Faktor syaraf } \\
\text { 2.Penyakit jiwa }\end{array}$ \\
\hline $\begin{array}{l}\text { 2.Faktor } \\
\text { Mikro }\end{array}$ & $\begin{array}{l}\text { 1.Praktik-praktik mengasuh } \\
\text { anak } \\
\text { 2.Pengaruh teman sebaya } \\
\text { 3.Pengaruh pelaksanaan } \\
\text { hukum }\end{array}$ & $\begin{array}{l}\text { 1.Dorongan nafsu berlebihan. } \\
\text { 2.Penilaian yang tidak tepat } \\
\text { kepada diri sendiri dan orang } \\
\text { lain. } \\
\text { 3.Pandangan terhadap diri } \\
\text { sendiri yang negatif. }\end{array}$ \\
\hline
\end{tabular}

Arifin, 1979 (dalam Samsul Munir Amin, 2008, hal. 380)

Pemberian layanan bimbingan dan konseling semakin diyakini kepentingannya bagi anak atau remaja, mengingat dinamika kehidupan masyarakat dewasa ini cenderung lebih kompleks, terjadi pembenturan antara berbagai kepentingan yang bersifat kompetitif, baik menyangkut aspek politik, ekonomi, ilmu pengetahuan dan teknologi, maupun aspek-aspek yang lebih khusus tentang pembenturan ideologi antara yang hak (benar) dan batil (salah).

Perkembangan ilmu pengetahuan dan teknologi, serta praktik-praktik kehidupan politik dan ekonomi yang tidak berlandaskan moral agama telah 
menyebabkan berkembangnya gaya hidup materialistik, dikalangan masyarakat, termasuk anak-anak dan remaja. Dampak yang lebih jauh dari gaya hidp tersebut adalah merebaknya dekadensi moral atau pelecehan nilai-nilai agama, baik di kalangan orang dewasa, remaja, maupun anak-anak.

Dekadensi moral itu seperti terjadinya kasus-kasus yang terkait dengan larangan 5M (Jawa: Mo limo), yaitu (1) Madat = Narkotika dan Miras; (2) Madon = berzina, prostitusi, free sex, atau kumpul kebo (samen leven); (3) Maling = korupsi, mencuri, mencopet, dan mengompas; (4) Main = berjudi, dan (5) Mateni $=$ membunuh (diri sendiri maupun orang lain).

Khusus mengenai dekadensi moral dalam kaitannya dengan perzinahan (free sex) di kalangan remaja yang merupakan bagian dari bentuk juvenile delinquency di beberapa kota besar di Indonesia sebagai berikut:

\begin{tabular}{|l|l|l|l|}
\hline No & \multicolumn{1}{|c|}{ Peneliti } & \multicolumn{1}{c|}{ Responden } & Yang Melakukan Seks Bebas \\
\hline 1 & Dr. Sarlito Wirawan & 800 remaja & 80 remaja \\
2 & Majalah Editor & 100 remaja & 40 remaja \\
\hline
\end{tabular}

Dr. Syamsu Yusuf, LN dan Dr. A.Juntika Nurihson (dalam Samsul Munir Amin, 2008, hal. 832)

Kenakalan remaja di beberapa kota besar di Indonesia dalam berbagai pemberitaan media semakin hari semakin meningkat. Kenakalan remaja ini dilakukan baik oleh remaja putra maupun putri. Hal ini tentu sangat memprihatinkan kalangan para pendidik.

Mengapa dekadensi moral (delinquency) khususnya kalangan remaja semakin marak? Dalam hal ini Zakiah Daradjat, 1973, hal 12 (dalam Samsul Munir Amin, 2008, hal. 383) mengemukakan bahwa masalah tersebut disebabkan beberapa faktor, seperti kurang tertanamnya jiwa agama pada tiaptiap orang dalam masyarakat, keadaan msyarakat yang kurang stabil, baik dari segi ekonomi, sosial, maupun politik, pendidikan moral tidak terlaksana 
menurut mestinya, baik di lingkungan keluarga, sekolah, maupun masyarakat, dijualnya dengan bebas berbagai alat kontrasepsi, dan iklim keluarga yang tidak harmonis.

\section{F. Kembali kepada Ajaran Agama}

Dalam kaitannya dengan perilaku bullying sebagai salah satu bentuk kenakalan remaja, data-data tentang dekadensi moral dan faktor-faktor penyebabnya perlu menjadi keprihatinan semua pihak, orang tua, maupun masyarakat pada umumnya untuk senantiasa berupaya antara pihak-pihak terkait untuk meningkatkan kualitas pendidikan (baik di lingkungan keluarga, sekolah mupun masyarakat), dan menciptakan lingkungan yang bersih dari kemaksiatan dan kemungkaran agar tercipta lingkungan kehidupan masyarakat yang kondusif dan religius.

Nilai-niai religiusitas menjadi faktor yang dominan dalam upaya pencegahan terjadinya kenakalan remaja dalam suatu lingkungan masyarakat. Berikut ini akan dikemukakan pendapat para ahli tentang pengaruh agama terhadap kesehatan mental.

1. William James (filosuf dan ahli psikologi Amerika) berpendapat sebagai berikut:

a. Tidak diragukan lagi bahwa terapi terbaik bagi keresahan adalah keimanan kepada Tuhan.

b. Keimanan kepada Tuhan merupakan salah satu kekuatan yang harus terpenuhi untuk menopang seseorang dalam hidup ini.

c. Antara kita dengan Tuhan terdapat suatu ikatan yang tidak terputus apabila kita menundukkan diri di bawah pengaruh-Nya, maka semua cita-cita dan harapan kita akan tercapai.

d. Gelombang lautan yang menggelora, sama sekali tidak membuat keruh relung hati yang dalam dan tidak membuat resah. Demikian halnya dengan 
individu yang keimanannya mendalam, ketenangannya tidak akan terkeruhkan oleh gejolak superficial yang sementara sifatnya. Sebab individu yang benarbenar religius akan berlindung dari keresahan, selalu terjaga keseimbangannya, dan selalu siap untuk menghadapi segala malapetaka yang terjadi.

2. Carl Gustave Jung (ahli psikoanalisis dari Jerman) mengemukakan, "Selama tiga puluh tahun yang lalu, pribadi-pribadi dari berbagai bangsa di dunia telah mengadakan konseling dengan saya, dan saya pun telah banyak menyembuhkan pasien, tidak saya dapatkan seorang pasien pun diantara yang telah berada pada penggal kedua umur mereka, yakni dari 35 tahun yang problem esensialnya bukan kebutuhan akan wawasan agama tentang kehidupan. Dan dapat saya katakan bahwa masing-masing mereka telah menjadi mangsa penyakit, sebab mereka telah kehilangan sesuatu yang telah diberikan oleh agama-agama yang ada di setiap masa. Sungguh, tidak ada seorang pun diantara mereka yang menjadi sembuh kecuali setelah ia kembali pada wawasan agama tentang kehidupan."

3. Arnold Toynbe (sejarawan Inggris) mengemukakan bahwa krisis yang diderita orang-orang Eropa pada zaman modern ini pada dasarnya terjadi karena kemiskinan ruhaniah dan terapi satu-satunya bagi penderita yang sedang mereka alami ialah kembali kepada agama.

4. Dadang Hawari (psikiater Indonesia) mengemukakan bahwa dari sejumlah penelitian para ahli bisa disimpulkan (1) komitmen agama dapat mencegah dan melindungi seseorang dari penyakit, meningkatkan kemampuan mengatasi penyakit, dan mempercepat pemulihan penyakit, (2) agama lebih bersifat protektif dari pada problem producing, dan (3) kemitmen agama mempunyai hubungan signifikan dan positif dengan clinical benefit.

5. Larson berpendapat, "untuk mengemudikan atau mengendalikan kompleksitas hubungan dan kesehatan manusia, maka komitmen terhadap agama merupakan suatu kekuatan yang patut diperhatikan.” 
6. Zakiah Darajat (psikolog muslimah Indonesia) mengemukakan, "Apabila manusia ingin terhindar dari kegelisahan, kecemasan, dan ketegangan jiwa serta ingin hidup tenang, tenteram, bahagia, dan dapat membahagiakan orang lain maka hendaklah manusia percaya kepada Tuhan dan hidup mengamalkan ajaran agama. Agama bukanlah dogma, tetapi agama adalah kebutuhan jiwa yang perlu dipenuhi."

Berdasarkan pendapat -pendapat yang dikemukakan di atas, dapat disimpulkan bahwa agama mempunyai pengaruh yang sangat besar terhadap kesehatan mental individu. Dengan demikian, dapatlah dikatakan bahwa individu tidak akan mencapai atau memiliki mental yang sehat tanpa keberadaan agama.

IV. Penutup.

Berdasarkan pembahasan di atas maka perilaku Bullying merupakan salah satu bentuk perilaku yang menyimpang dari pola perilaku individu/siswa pada umumnya. Perilaku tersebut sering digunakan oleh remaja dalam hal ini adalah siswa untuk menindas temannya yang lebih lemah. Bentuk-bentuk perilaku yang berupa pemaksaan atau usaha menyakiti secara fisik maupun psikologis terhadap seseorang atau kelompok yang lebih "lemah" oleh seseorang atau sekelompok orang yang mempersepsikan dirinya "kuat". Bullying adalah penggunaan kekuasaan atau kekuatan untuk menyakiti seseorang atau sekelompok, sehingga korban merasa tertekan, trauma dan tidak berdaya. Perilaku bullying dapat dikategorikan salah satu bentuk kenakalan remaja atau siswa di sekolah.

Upaya preventif dan kuratif yang dapat dilakukan untuk menyelesaikan masalah tersebut adalah dengan cara lebih mengajak siswa me ningkatkan pemahaman dan pengalaman ajaran agama sesuai dengan keyakinan atau agamanya masing-masing, salah diantara agama yang ada yaitu ajaran agama islam. 


\section{DAFTAR PUSTAKA}

Aunur Rahim Faqih, 2001, Bimbingan dan Konseling Dalam Islam, Yogyakaerta, LPPAI UII Press.

Anwar Sutoyo, 2007, Bimbingan dan Konseling Islami, Semarang, Penerbit Cipta Prima Nusantara.

Giri Rahendra. 2012. Pengaruh Perilaku Bullying dan Kepercayaan Diri Terhadap Minat Belajar Siswa Kelas VIII SMP Negeri 1 Maospati.

Samsul Munir Amin, 2008, Bimbingan Dan Konseling Islam, Wonosobo, Penerbit Amzah. 